\title{
Kidney cancer mortality in Spain: geographic patterns and possible hypotheses
}

\author{
Gonzalo López-Abente*1,2, Nuria Aragonés ${ }^{1,2}$, Beatriz Pérez-Gómez ${ }^{1,2}$, \\ Rebeca Ramis ${ }^{1,2}$, Enrique Vidal1,2, Javier García-Pérez ${ }^{1,2}$, Pablo Fernández- \\ Navarro $^{1,2}$ and Marina Pollán ${ }^{1,2}$
}

Address: ${ }^{1}$ Cancer and Environmental Epidemiology Area, National Centre for Epidemiology, Carlos III Institute of Health, Sinesio Delgado 6, 28029 Madrid, Spain and 2CIBER Epidemiología y Salud Pública (CIBERESP), Madrid, Spain

Email: Gonzalo López-Abente* - glabente@isciii.es; Nuria Aragonés - naragones@isciii.es; Beatriz Pérez-Gómez - bperez@isciii.es; Rebeca Ramis - rramis@isciii.es; Enrique Vidal - evidal@isciii.es; Javier García-Pérez - jgarcia@isciii.es; Pablo FernándezNavarro - pfernandezn@isciii.es; Marina Pollán - mpollan@isciii.es

* Corresponding author

Published: 9 October 2008

BMC Cancer 2008, 8:293 doi:10.1 |86/147|-2407-8-293
Received: 2 June 2008

Accepted: 9 October 2008

This article is available from: http://www.biomedcentral.com/I47I-2407/8/293

(c) 2008 López-Abente et al; licensee BioMed Central Ltd.

This is an Open Access article distributed under the terms of the Creative Commons Attribution License (http://creativecommons.org/licenses/by/2.0), which permits unrestricted use, distribution, and reproduction in any medium, provided the original work is properly cited.

\begin{abstract}
Background: Since the second half of the 1990s, kidney cancer mortality has tended to stabilize and decline in many European countries, due to the decrease in the prevalence of smokers. Nevertheless, incidence of kidney cancer is rising across the sexes in some of these countries, a trend which may possibly reflect the fact that improvements in diagnostic techniques are being outweighed by the increased prevalence of some of this tumor's risk factors. This study sought to: examine the geographic pattern of kidney cancer mortality in Spain; suggest possible hypotheses that would help explain these patterns; and enhance existing knowledge about the large proportion of kidney tumors whose cause remains unknown.
\end{abstract}

Methods: Smoothed municipal relative risks (RRs) for kidney cancer mortality were calculated in men and women, using the conditional autoregressive model proposed by Besag, York and Molliè. Maps were plotted depicting smoothed relative risk estimates, and the distribution of the posterior probability of $R R>I$ by sex.

Results: Municipal maps displayed a marked geographic pattern, with excess mortality in both sexes, mainly in towns along the Bay of Biscay, including areas of Asturias, the Basque Country and, to a lesser extent, Cantabria. Among women, the geographic pattern was strikingly singular, not in evidence for any other tumors, and marked by excess risk in towns situated in the Salamanca area and Extremaduran Autonomous Region. This difference would lead one to postulate the existence of different exposures of environmental origin in the various regions.

Conclusion: The reasons for this pattern of distribution are not clear, and it would thus be of interest if the effect of industrial emissions on this disease could be studied. The excess mortality observed among women in towns situated in areas with a high degree of natural radiation could reflect the influence of exposures which derive from the geologic composition of the terrain and then become manifest through the agency of drinking water. 


\section{Background}

During the 1980s and 90s, kidney cancer mortality increased throughout Europe. There was a trend towards stabilization in subsequent years, though this was principally in western European countries, with the rates continuing to be very high in the eastern European countries [1]. The incidence of these tumors follows a trend which, though very similar to that of mortality in a good number of countries, is not in others, where it continues to rise across the sexes (e.g., Norway, Ireland, UK England, UK Scotland) $[1,2]$. In the closing decades of the $20^{\text {th }}$ century, mortality due to this tumor registered an annual increase in Spain of $2.9 \%$ among men and $1.4 \%$ among women [3], and it is estimated that there were approximately 4000 new cases in 2002 [4]. The most frequent histologic type of kidney cancer in Spain is renal cell carcinoma (RCC) (accounting for around 80\% of cases), followed by transitional cell carcinomas of the renal pelvis, ureter and urethra [2]. The male:female incidence ratio is $2: 1$, though adjusted rates vary from $4.8-11.3$ cases per 100,000 population in men, to 2.3-4.1 in women, depending upon the geographic area in question [2]. It has been argued that the growing incorporation in recent decades of new diagnostic techniques, such as echography, computed tomography, and magnetic resonance imaging, may have had an influence on the observed rise in incidence [5], though the most recent reviews conclude that the described increase is associated with the rise in prevalence of this tumor's risk factors [6].

Established risk factors for kidney cancer include cigarette smoking, obesity, diabetes, and hypertension [7]. However, these factors are thought to explain only half the incidence $[5,8]$. In the scientific literature other risk factors have been proposed, such as ingestion of some drugs (phenacetin, diuretics) [9], intake of certain dietary components (doneness of red meat) [10], or consumption of tea and coffee, with controversial results [7]. With respect to alcohol consumption, most studies (with differing designs) report no association with kidney cancer, though some do cite evidence of a possible protective effect found exclusively among women [11], exclusively among men [12], or in both sexes [13].

Another possible, less studied risk factor for kidney cancer is exposure to substances contained in drinking water, such as products resulting from disinfection of the water $[14,15]$, nitrites, precursors of $\mathrm{N}$-nitroso compounds $[16,17]$ and some radionuclides. Regarding this last exposure, water from bedrock frequently contains higher concentrations of natural radionuclides than does water from other sources. Bladder and kidneys receive a radiation dose when radioactive isotopes are excreted into urine [18]. Studies conducted in Spain $[19,20]$ and those under- taken in other countries [21] coincide in concluding that there is a wide variability of content in natural radionuclides depending upon the nature of the terrain and the geographic location, something that might in turn have a bearing on the spatial patterns of this disease.

Spatial analysis of health events (spatial epidemiology) is a discipline that, albeit still in the development phase, is already enjoying a space of its own in the field of health research $[22,23]$. Its ability to suggest and detect the possible sources of heterogeneity (generally of environmental origin) which determine the spatial patterns of incidence and mortality due to different diseases, imbues this tool with great interest in the sphere of epidemiology and public health. Its potential is, moreover, being reinforced by the ever increasing availability of geographically-indexed population mortality and incidence data, together with advances in computation techniques and Geographic Information Systems. These circumstances are favoring the analysis of the geographical distribution of health data with growing levels of disaggregation [24], a field that encompasses the so-called small-area studies.

The aim of this study was to show the spatial distribution patterns of kidney cancer in men and women, and discuss, in the light of known risk factors, possible hypotheses that would help explain these patterns and enhance existing knowledge about the large proportion of kidney tumors whose cause remains unknown.

\section{Methods}

As case source, we used individual death entries for the period 1989-1998 corresponding to kidney cancer (International Classification of Diseases, $9^{\text {th }}$ Revision/ICD-9 code 189), broken down by town or city, nationwide. These data were furnished by the National Statistics Institute (Instituto Nacional de Estadística - INE) for the production of a municipal cancer mortality atlas, of which these results form part [25].

Municipal populations, broken down by age group (18 groups) and sex, were obtained from the 1991 census and 1996 municipal roll. These years correspond to the midpoints of the two quinquennia that comprise the study period (1989-1993 and 1994-1998). The person-years for each five-year period were obtained by multiplying these populations by 5 .

Standardized mortality ratios (SMR) were calculated as the ratio of observed to expected deaths. To calculate expected cases, the overall Spanish mortality rates for the above two 5-year periods were multiplied by each town's person-years, broken down by age group, sex and quinquennium. 
For map-plotting purposes, smoothed municipal relative risks (RRs) were calculated using the conditional autoregressive model proposed by Besag, York and Molliè (BYM). This model was introduced by Clayton and Kaldor [26], developed by Besag, York and Molliè [27], and subsequently applied in the field of ecological studies [28]. These models are based on fitting Poisson spatial models with observed cases as the dependent variable, expected cases as offset, and two types of random effects terms which take the following into account: a) municipal contiguity (spatial term); and b) municipal heterogeneity. The models were fitted using Markov chain Monte Carlo simulation methods with non-informative priors [29]. Posterior distributions of relative risk were obtained using WinBugs [30]. The criterion of contiguity used was adjacency of municipal boundaries. Convergence of the simulations was verified using the BOA (Bayesian Output Analysis) R program library [31]. Given the great number of parameters of the models, the convergence analysis was performed on a randomly selected sample of 10 towns and cities, taking 4 strata defined by municipal size. Convergence of the estimators was achieved before 100,000 iterations. For the maps shown, a "burn-in" (iterations discarded to ensure convergence) of 300,000 iterations was performed and the posterior distribution was derived with 5,000.

A Geographic Information System was used to plot municipal maps that depicted smoothed RR estimates and the distribution of the posterior probability (pp) that $R R>1$ (Bayesian version of $p$ value). With regard to this indicator, we followed Richardson's criterion [32], which recommends that probabilities above 0.8 should be deemed significant. Separate analyses were performed for men and women.

\section{Results}

From 1989 to 1998 , a total of 14116 kidney cancer deaths were registered in Spain, 9431 among men and 4685 among women. In 5220 towns and cities no death due to this cause was registered. Using these data and conventional computers, it was possible to compile and ascertain the posterior distribution of relative risk on the basis of a single spatial model that included all of Spain's 8077 towns and cities and the 46398 adjacencies existing between them.

To give an overall picture, Figure 1 depicts kidney cancer mortality by province for both sexes. There were only six provinces with SMRs greater than 1.15, namely, Alava, Guipuzcoa, Biscay, Navarre, Asturias and Badajoz. The lowest SMRs were registered in Galicia, Aragon, the Valencian Region, Murcian Region and Mediterranean provinces of Andalusia. Table 1 shows the results for observed and expected deaths by province, in order to be able to assess the magnitude of the relative risk and differences by sex.

Figures 2 and 3 depict the distribution of: a) the smoothed RRs for kidney cancer in men and women; and, b) the posterior probability (pp) that $R R>1$. This second map "filters" the previous one, flagging the areas in which excess mortality is more likely.

As the patterns for each sex displayed notable similarities and differences [25], the respective results are shown separately. The maps show that the highest mortality in both sexes was concentrated in towns along the Bay of Biscay coastline of the Asturian, Cantabrian and Basque Country Autonomous Regions. The different mortality pattern registered by women was noteworthy, with excess risk in the west of the country, covering wide swathes of Salamanca and Extremadura. In men, the only excess mortality observed in this area exclusively affected two towns, i.e., Badajoz and Mérida.

\section{Discussion}

Municipal maps of kidney cancer distribution display a marked geographic pattern, with excess mortality in both sexes chiefly in towns along the Bay of Biscay, including areas of Asturias, the Basque Country and, to a lesser extent, Cantabria. Among women, special mention must be made of the existence of a strikingly singular pattern, not in evidence for any other tumors and marked by excess risk in towns situated in the Salamanca area and Extremaduran Autonomous Region. This difference would lead one to postulate the existence of different exposures of environmental origin in the various regions.

Possible misclassification errors involved in the study of RCC mortality render a high degree of caution necessary when it comes to assessing the patterns observed in the results. Despite the fact that undercertification of renal cancers has been reported by studies on the accuracy of death certification in Spain [33], there are not too many arguments that would support possible inconsistencies and differences of criteria in the coding of death certificates, i.e., if the certification/coding of deaths were not correct, the errors would not necessarily follow any pattern, and there would be no agreement between incidence and mortality data. Another explanations for possible differences in kidney cancer mortality across the country, as differences in survival rates due to the distribution of tumor stage at diagnosis are difficult to maintain because the universal accessibility to the health care system. Bearing in mind the characteristics of the Spanish National Health Care System, we would have no reason to suspect that there might be differential access to health care and diagnosis between regions. 
Table I: Kidney cancer mortality by province: Spain, 1989-1998.

\begin{tabular}{|c|c|c|c|c|c|c|c|c|c|c|c|}
\hline \multirow[b]{2}{*}{ Province } & \multicolumn{3}{|c|}{ TOTAL } & \multicolumn{4}{|c|}{ MEN } & \multicolumn{4}{|c|}{ WOMEN } \\
\hline & obs & $\exp$ & SMR & obs & $\exp$ & SMR & p-val & obs & $\exp$ & SMR & p-val \\
\hline ALMERIA & 108 & 147.4 & 0.733 & 81 & 100.2 & 0.809 & 0.972 & 27 & 47.3 & 0.571 & 0.999 \\
\hline CADIZ & 301 & 284.7 & 1.057 & 201 & 191.1 & 1.052 & 0.224 & 100 & 93.6 & 1.069 & 0.234 \\
\hline CORDOBA & 266 & 265.6 & 1.002 & 183 & 176.7 & 1.036 & 0.301 & 83 & 88.9 & 0.933 & 0.713 \\
\hline GRANADA & 236 & 262.2 & 0.900 & 144 & 177.3 & 0.812 & 0.994 & 92 & 84.9 & $\mathrm{I} .084$ & 0.203 \\
\hline HUELVA & 131 & 147.9 & 0.886 & 87 & 98.2 & 0.886 & 0.861 & 44 & 49.7 & 0.885 & 0.768 \\
\hline JAEN & 194 & 230.9 & 0.840 & 134 & 157.4 & 0.851 & 0.969 & 60 & 73.5 & 0.816 & 0.939 \\
\hline MALAGA & 331 & 363.5 & 0.911 & 210 & 245 & 0.857 & 0.988 & 121 & 118.4 & 1.022 & 0.384 \\
\hline SEVILLE & 506 & 483.9 & 1.046 & 330 & 319.5 & 1.033 & 0.268 & 176 & 164.4 & $1.07 \mid$ & 0.172 \\
\hline HUESCA & 80 & 107.1 & 0.747 & 49 & 75.1 & 0.652 & 0.999 & 31 & 32 & 0.970 & 0.520 \\
\hline TERUEL & 66 & 79 & 0.835 & 39 & 54.8 & 0.712 & 0.984 & 27 & 24.2 & 1.114 & 0.248 \\
\hline ZARAGOZA & 338 & 351.7 & 0.961 & 235 & 236.1 & 0.995 & 0.512 & 103 & 115.5 & 0.892 & 0.869 \\
\hline ASTURIAS & 640 & 463.8 & 1.38 & 447 & 304.8 & 1.466 & $<0.001$ & 193 & 158.9 & 1.214 & 0.004 \\
\hline BALEARIC ISLES & 240 & 263.1 & 0.912 & 169 & 177.1 & 0.954 & 0.713 & 71 & 86 & 0.825 & 0.945 \\
\hline LAS PALMAS & 184 & 199.3 & 0.923 & 133 & 136.9 & 0.971 & 0.610 & 51 & 62.4 & 0.818 & 0.919 \\
\hline SANTA CRUZ & 135 & 215.7 & 0.626 & 93 & 146.5 & 0.635 & 1 & 42 & 69.3 & 0.606 & I \\
\hline CANTABRIA & 234 & 206.7 & 1.132 & 163 & 136.5 & 1.194 & 0.012 & 71 & 70.2 & 1.011 & 0.431 \\
\hline ALBACETE & 85 & 132.3 & 0.642 & 54 & 91.2 & 0.592 & 1 & 31 & 41.1 & 0.755 & 0.937 \\
\hline CIUDAD REAL & 174 & 189.9 & 0.916 & 104 & 127.6 & 0.815 & 0.982 & 70 & 62.3 & 1.124 & 0.149 \\
\hline CUENCA & 72 & 103.1 & 0.698 & 43 & 71.4 & 0.602 & I & 29 & 31.7 & 0.916 & 0.640 \\
\hline GUADALAJARA & 66 & 72.8 & 0.907 & 46 & 50.9 & 0.904 & 0.725 & 20 & 21.9 & 0.912 & 0.608 \\
\hline TOLEDO & 223 & 209.7 & 1.063 & 150 & 143.6 & 1.044 & 0.281 & 73 & 66.1 & 1.104 & 0.180 \\
\hline AVILA & 76 & 89.1 & 0.853 & 54 & 61.7 & 0.876 & 0.819 & 22 & 27.4 & 0.802 & 0.826 \\
\hline BURGOS & 163 & 154.4 & 1.056 & 114 & 105.1 & 1.084 & 0.180 & 49 & 49.3 & 0.995 & 0.477 \\
\hline LEON & 230 & 237.6 & 0.968 & 137 & 160.8 & 0.852 & 0.969 & 93 & 76.8 & 1.210 & 0.032 \\
\hline PALENCIA & 76 & 82.2 & 0.924 & 55 & 54.8 & 1.003 & 0.454 & 21 & 27.4 & 0.767 & 0.872 \\
\hline SALAMANCA & 165 & 166.4 & 0.992 & 100 & 112.3 & 0.891 & 0.867 & 65 & 54.1 & 1.200 & 0.065 \\
\hline SEGOVIA & 56 & 71.9 & 0.779 & 39 & 49.1 & 0.795 & 0.918 & 17 & 22.8 & 0.747 & 0.868 \\
\hline SORIA & 52 & 53.3 & 0.976 & 37 & 36.5 & 1.015 & 0.422 & 15 & 16.8 & 0.891 & 0.613 \\
\hline VALLADOLID & 197 & 176 & 1.119 & 128 & 118.3 & 1.082 & 0.174 & 69 & 57.7 & 1.197 & 0.063 \\
\hline ZAMORA & 93 & $1 \mid 4.5$ & 0.812 & 60 & 77.8 & 0.771 & 0.978 & 33 & 36.7 & 0.898 & 0.697 \\
\hline BARCELONA & 1710 & 1669 & 1.025 & 1125 & 1098.6 & 1.024 & 0.208 & 585 & 570.4 & 1.026 & 0.262 \\
\hline GERONA & 211 & 204 & 1.034 & 140 & 138.9 & 1.008 & 0.440 & 71 & 65.1 & 1.091 & 0.212 \\
\hline LERIDA & 125 & 163.5 & 0.765 & 83 & 113.8 & 0.729 & 0.998 & 42 & 49.7 & 0.845 & 0.847 \\
\hline TARRAGONA & 212 & 219.5 & 0.966 & 145 & 150.1 & 0.966 & 0.641 & 67 & 69.4 & 0.965 & 0.583 \\
\hline ALICANTE & 401 & 459.8 & 0.872 & 283 & 313.3 & 0.903 & 0.956 & 118 & 146.4 & 0.806 & 0.991 \\
\hline CASTELLON & 164 & 181.8 & 0.902 & 110 & 124.1 & 0.886 & 0.890 & 54 & 57.8 & 0.935 & 0.659 \\
\hline VALENCIA & 676 & 749.8 & 0.902 & 462 & 500.8 & 0.923 & 0.958 & 214 & 249.1 & 0.859 & 0.987 \\
\hline BADAJOZ & 286 & 242.2 & 1.181 & 179 & 161.6 & 1.108 & 0.081 & 107 & 80.6 & 1.327 & 0.002 \\
\hline CACERES & 181 & 169.6 & 1.067 & 110 & 114 & 0.965 & 0.622 & 71 & 55.6 & 1.277 & 0.020 \\
\hline CORUNNA & 377 & 426.9 & 0.883 & 243 & 278.1 & 0.874 & 0.983 & 134 & 148.8 & 0.900 & 0.881 \\
\hline LUGO & 132 & 207.4 & 0.637 & 80 & $|4| .3$ & 0.566 & I & 52 & 66 & 0.787 & 0.956 \\
\hline ORENSE & 130 & 191.1 & 0.68 & 75 & 127.6 & 0.588 & I & 55 & 63.5 & 0.866 & 0.842 \\
\hline PONTEVEDRA & 274 & 311.6 & 0.879 & 179 & 199.9 & 0.895 & 0.927 & 95 & 111.7 & 0.851 & 0.940 \\
\hline MADRID & 1788 & 1588.3 & 1.126 & 1234 & 1035.2 & 1.192 & $<0.001$ & 554 & 553.1 & 1.002 & 0.474 \\
\hline MURCIA & 266 & 338.6 & 0.786 & 185 & 229 & 0.808 & 0.998 & 81 & 109.6 & 0.739 & 0.997 \\
\hline
\end{tabular}


Table I: Kidney cancer mortality by province: Spain, 1989-1998. (Continued)

\begin{tabular}{|c|c|c|c|c|c|c|c|c|c|c|c|}
\hline NAVARRE & 249 & 209.8 & 1.187 & 170 & 138.8 & 1.225 & 0.005 & 79 & 71 & 1.112 & 0.157 \\
\hline ALAVA & 123 & 91.4 & 1.345 & 82 & 62.3 & 1.316 & 0.007 & 41 & 29.1 & 1.408 & 0.014 \\
\hline GUIPUZCOA & 360 & 238.5 & 1.509 & 227 & 157.3 & 1.443 & $<0.001$ & 133 & 81.2 & 1.637 & $<0.001$ \\
\hline VIZCAYA & 563 & 406.6 & 1.385 & 386 & 269.7 & 1.431 & $<0.001$ & 177 & 136.9 & 1.293 & $<0.001$ \\
\hline LA RIOJA & 121 & 111.2 & 1.088 & 87 & 75.6 & 1.151 & 0.088 & 34 & 35.6 & 0.955 & 0.563 \\
\hline CEUTA & 32 & 17.3 & 1.847 & 19 & 11.6 & 1.642 & 0.015 & 13 & 5.7 & 2.262 & 0.002 \\
\hline MELILLA & 17 & 13.8 & 1.23 & 8 & 9.1 & 0.875 & 0.564 & 9 & 4.7 & 1.926 & 0.021 \\
\hline
\end{tabular}

Observed and expected cases, SMRs and p-values shown for both sexes, men and women. Provinces grouped by autonomous region. SMR: Standardised mortality ratio

On examining the incidence data reported in officially certified Spanish population cancer registers and published in "Cancer Incidence in Five Continents, Volume IX" [2], the coincidence with mortality patterns can be appreciated. The highest incidence rates for both sexes were those registered in the Basque Country and Asturian Autonomous Communities (1998-2001), there being no data for the Provinces of Salamanca, Cáceres and Badajoz, as population-registry-based information is still lacking in these areas.

Smoking habit is the most widely established risk factor for both histologic types of kidney cancer [34]. Yet, the patterns shown in the maps presented here diverge considerably from the patterns described for lung and bladder cancer among men and women, respectively [35]. Neither is there any concordance between the geographic pattern

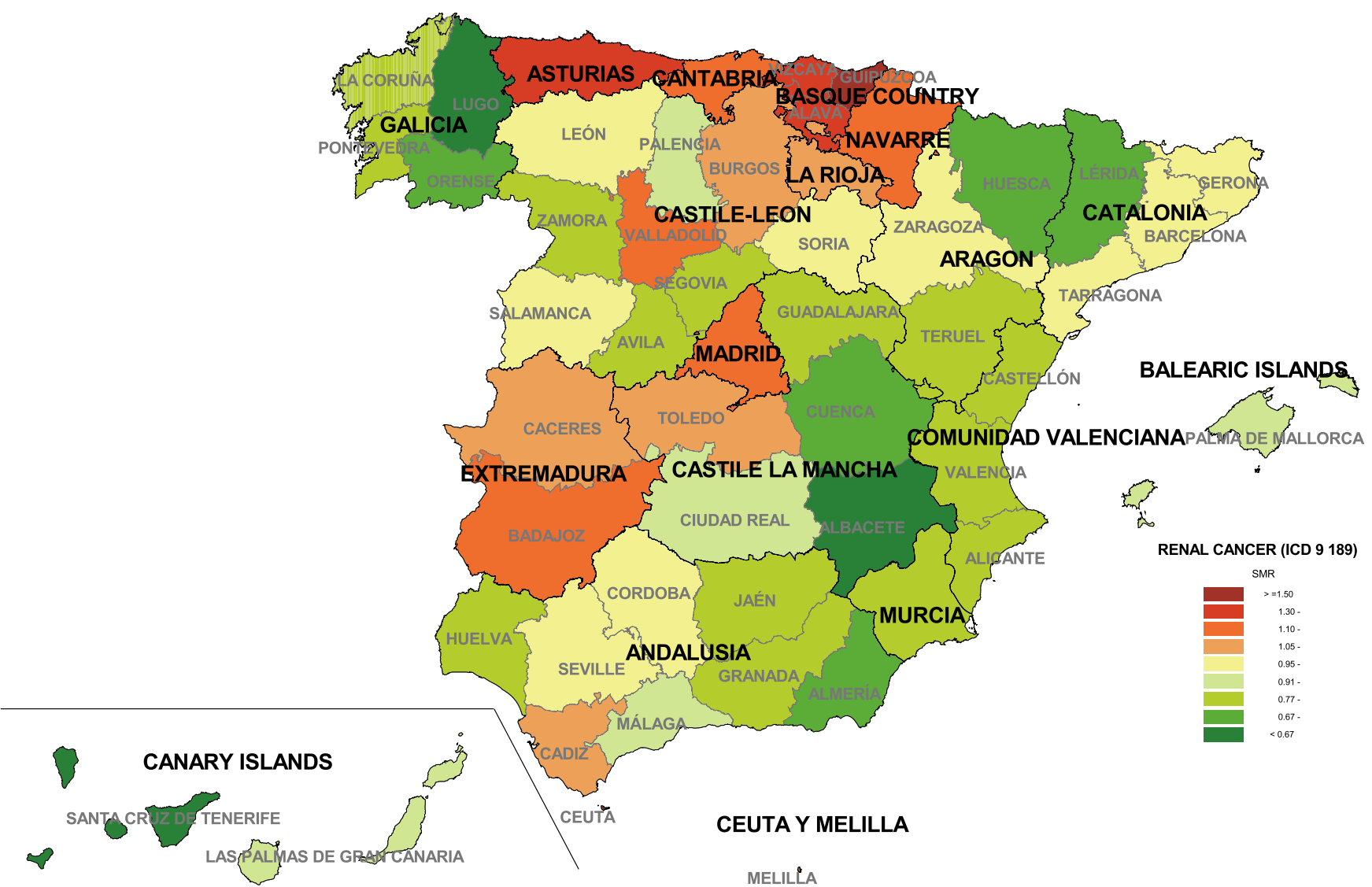

Figure I

Provincial distribution of kidney cancer mortality: Spain, I 989-1998. 

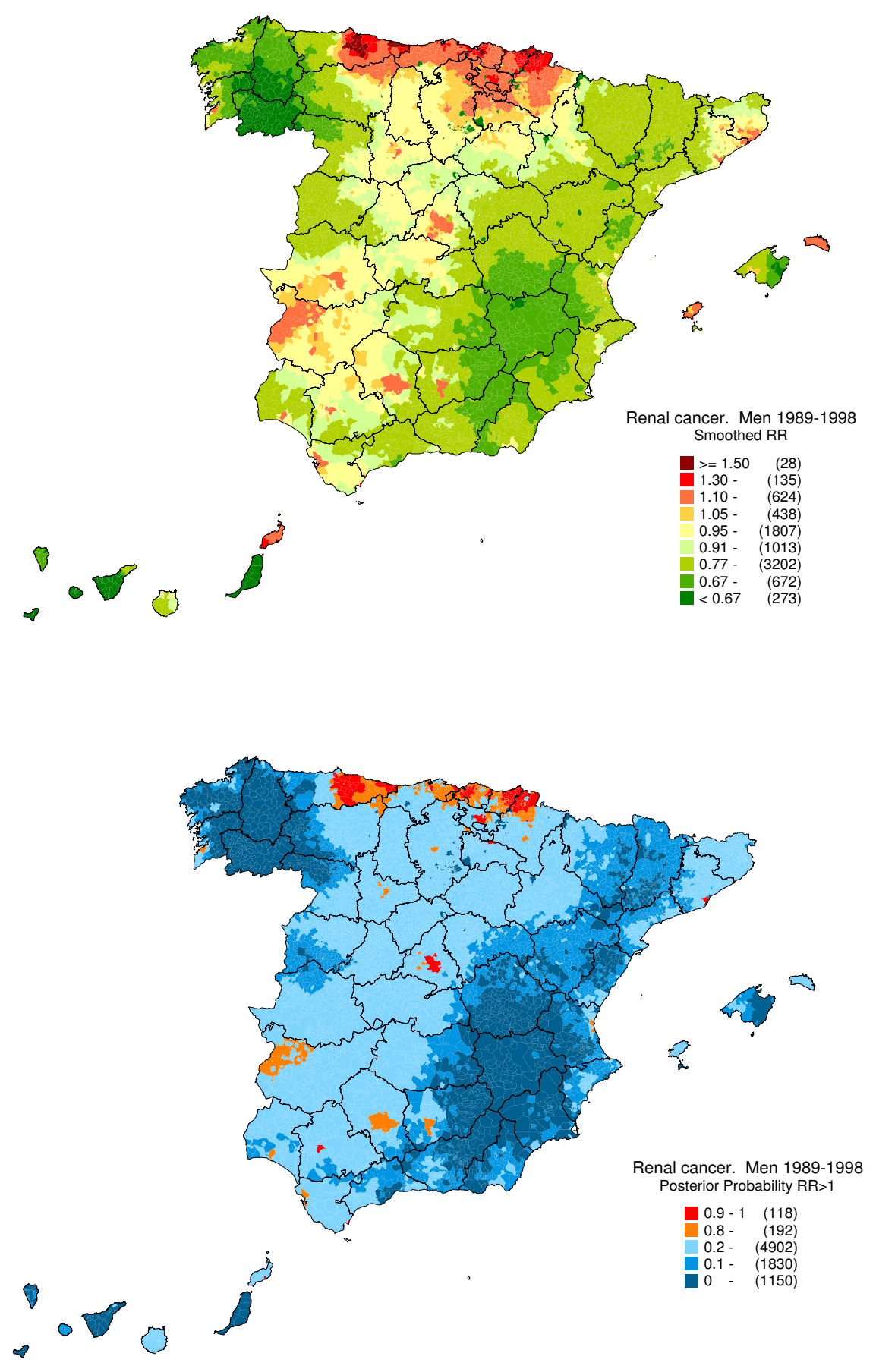

Figure 2

Municipal distribution of kidney cancer mortality in men: Spain, 1989-1998. Distribution pattern of the smoothed relative risk under the BYM model and posterior probability of RR being greater than I. 

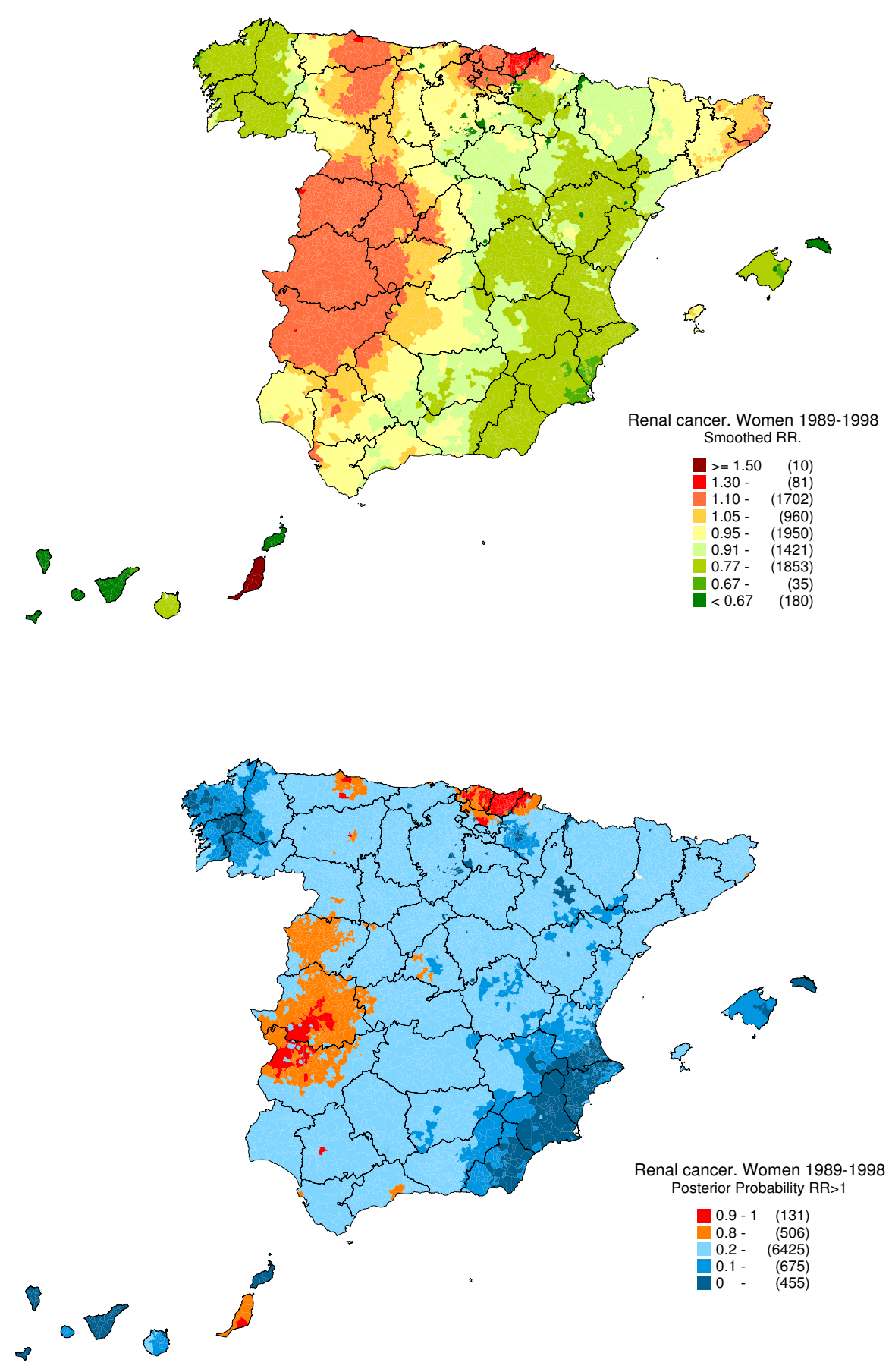

Figure 3

Municipal distribution of kidney cancer mortality in women: Spain, 1989-1998. Distribution pattern of the smoothed relative risk under the BYM model and posterior probability of RR being greater than $\mathrm{I}$. 
observed and the prevalence of obesity. Specifically, insofar as prevalence of obesity among women aged 35-64 years is concerned, only one of the provinces with excess risk, Badajoz, figures among the 10 provinces with highest prevalences of obesity [36].

Areas with excess kidney cancer mortality along the coast of the Bay of Biscay also register higher mortality due to other smoking-related tumors, among men in particular. As has been remarked above, however, the pattern of kidney cancer mortality is not concordant with that observed for other causes of death strongly related with tobacco [25]. Similarly, excess mortality due to ischemic heart or cerebrovascular diseases is not observed along the coast of the Bay of Biscay, so that other risk factors described (cigarette smoking, obesity, diabetes, and hypertension)[7] would not appear to explain this pattern. Attention should be drawn to the fact that excess kidney cancer on the Bay of Biscay is located in a heavily industrialized area (mining and heavy metal industry). As shown in the European Pollutant Emission Register (EPER), this area receives the highest industrial cadmium, arsenic, nickel and benzene emissions in Spain [37], substances which are classified in IARC group 1 in terms of their carcinogenic activity (human carcinogens) [38] and for which an association with renal cancer has been documented [3943]. Nonetheless, no references could be found in the literature which analyze the possible influence of industrial pollution on RCC.

The pattern displayed by female mortality in western parts of central mainland Spain (Salamanca, Cáceres, and Badajoz) is somewhat fuzzy, with smoothed RRs not exceeding 1.3 , and posterior probabilities of $\mathrm{RR}>1$ exceeding 0.80 over wide areas and reaching 0.90 in very few towns, something that could be interpreted as a consequence of the smoothing procedure. However, this possible artifact should affect other areas, and yet it would not appear to do so.

Taking the late introduction of the smoking habit among Spanish women into account [36], the peculiarities of the pattern displayed in women can be assumed to be attributable to other factors (dietary or environmental). Reviewing the known risk factors and possible explanations for the higher risk of this disease among women in the province of Salamanca and Extremadura, there are very few environmental components: 1) to which women might be more exposed; and 2) for which the kidney might be the target organ. Given the geologic composition of the terrain in these provinces [44,45], consumption of drinking water is one of the possibilities that could fit such a scenario. As men consume more alcohol than women, their liquid intake can be surmised to involve a lower consumption of publicly supplied water, water that may contain components which, in the context of chronic exposure, could well cause some form of renal toxicity. It has been shown that chronic ingestion of certain radionuclides (uranium) in drinking water may affect renal function [46]. Due to the lower prevalence of smokers among women, the effect of environmental factors might be more visible among them, since the presence of a risk factor such as tobacco, with a far higher RR, would partially mask the influence of environmental factors whose effect magnitude was substantially lower.

Salamanca, Cáceres and Badajoz are all provinces rich in uranium ore, and in one of them concentrations of radionuclides ( $\mathrm{U}, \mathrm{Th}, \mathrm{Ra}$ ) in groundwater (bedrock) have been found which were 5-30 times higher than in surface water, whereas one third of the samples contained Ra concentrations that exceeded the recommended limits [45]. In this respect, it must be said that the percentage of the population relying on a groundwater supply is $23 \%$ in Castile-León and 33\% in Extremadura [47].

On the other hand, there is evidence of the existence of other granitic areas in Galicia, where natural radiation is high [44] and yet no excess risk of kidney cancer has been observed. The radiologic situation of this area's drinking water is not known because no systematic studies have been undertaken [48]. In this Autonomous Region the percentage of the population supplied with groundwater is $12 \%$, a figure very much lower than that for Spain as a whole [47]. Due to their chalky soils and highly mineralized waters, the areas in Spain that register the maximum consumption of bottled water are the Balearic Isles, Catalonia, the Valencian Region, Castile-La Mancha, Murcia, and Aragon [49], and these same areas are shown in the maps as having lower-than-expected kidney cancer mortality.

A growing number of cohort studies have reported that alcohol consumption has a protective effect as against risk of RCC: in men [50]; in women [12,51]; or in both [52]. The mechanism of action whereby alcohol serves to reduce RCC risk has not been elucidated. Some authors are of the opinion that it may be the ethanol itself that produces the protective effect, since the effect is not confined to any one type of alcoholic beverage. In the studies consulted, no estimate is made of the effect of the reduction in daily water intake attributable to consumption of alcoholic beverages. Mean daily intake of water in Spain is $1,574.4 \mathrm{ml}$ (+- 327) among adults (aged over 17 years) [53]. Regardless of the fact that moderate consumption of alcohol has a slightly protective effect vis-à-vis RCC [54], persons who received an important part of their liquid intake in the form of alcoholic beverages (e.g., wine or beer) would be far less exposed to agents conveyed in 
publicly piped drinking water, whether from surface or underground sources.

The nationwide survey on diet and eating habits points to estimated alcohol consumption as being very much higher in men. The prevalence of male alcohol consumers in these provinces is extremely high $72 \%$ and $74 \%$ male vs. $38 \%$ and $47 \%$ female alcohol consumers in Extremadura and Castile-Leon, respectively) [36].

Exposure to products resulting from the disinfection of water is also being targeted for study in connection with urinary bladder tumors $[55,56]$, though ecologic mortality [14] and experimental animal research studies suggest a possible relationship with renal tumors $[57,58]$.

Other compounds related with the water supply are nitrates. Nitrate has steadily accumulated in our water supply and is the most common chemical contaminant in the world's groundwater aquifers [17]. In agricultural regions, nitrate inputs are largely due to nitrogen fertilizer use [59]. Nitrates are a precursor in the formation of $\mathrm{N}$ nitroso compounds (NOC), most of which are animal carcinogens [60]. Specific NOC cause renal cancers in animal studies [61]. Other sources of NOC exposure include preformed NOC found in preserved meats and fish, tobacco, and certain occupational exposures [62].

Nitrate contamination of groundwater in Spain seriously affects $(>50 \mathrm{mg} / \mathrm{l})$ the entire Mediterranean seaboard, which displays no excess risks of kidney cancer in either sex. Among the most affected inland areas are the Manchegan plain, the Ebro delta and some sections of the Guadalquivir valley. Locally, the presence of nitrates affects different areas of the Duero (central Duero, EslaValderaduey, and Arenales), Tagus (La Alcarria, Tiétar and Ocaña), Sur (Campo de Níjar, Dalías, and Fuente Piedra), and Segura river basins (Campo de Cartagena, Guadalentín, and Vegas del Segura). At a lower degree of intensity (25 through $50 \mathrm{mg} / \mathrm{l}$ ), this contamination affects many water supply points across Asturias and the Basque Country [63].

\section{Conclusion}

Municipal kidney cancer distribution maps display a marked geographic pattern. The maps show that highest mortality in both sexes is concentrated in towns along the Bay of Biscay, covering areas of Asturias, the Basque Autonomous Region and, to a lesser extent, Cantabria. The reasons for this pattern of distribution are not at all clear, and it would thus be of interest to study the effect of industrial emissions and immissions on this disease. Interventions targeted at decreasing prevalence of smoking, obesity and, perhaps, hypertension might tend to stabilize or reduce the incidence and mortality, and only go some way towards mitigating the geographic differences displayed. The different pattern registered by female mortality in towns in the Salamanca area and the Extremaduran Autonomous Region is noteworthy but, subject in all cases to the necessary caution, this could in part be explained by exposures linked to the geologic composition of the terrain and, in turn, to the local drinking water.

\section{Competing interests}

The authors declare that they have no competing interests.

\section{Authors' contributions}

GLA, MP, NA, and BPG were all involved in designing the study. GLA and RR performed the statistical analysis. GLA wrote the first draft of the manuscript to which all authors subsequently contributed. All authors made contributions to the statistical analyses and interpretation of results, and revised the manuscript for important intellectual content. All authors read and approved the final manuscript.

\section{Acknowledgements}

This study was financed by Grant No. EPY-I I 76/02 from the Carlos III Institute of Health (ISCIII) and the Consortium for Biomedical Research in Epidemiology \& Public Health (CIBERESP). The authors would like to thanks Diana Gómez-Barroso for her help with the mapping and Pilar Martín Lozano for her assistance with the bibliographic material.

\section{References}

I. Levi F, Ferlay J, Galeone C, Lucchini F, Negri E, Boyle P, La Vecchia C: The changing pattern of kidney cancer incidence and mortality in Europe. BJU Int 2008, I 01 (8):949-958.

2. Curado M, Edwards B, Shin H, Storm H, Ferlay J, Heanue M, et al.: Cancer Incidence in Five Continents Lyon 2008, IX:.

3. Lopez-Abente G, Pollan M, Aragones N, Perez-Gomez B, Llácer A, Pérez J, et al.: Tendencias de la mortalidad en España, 1952-1996. Efecto de la edad, de la cohorte de nacimiento y del periodo de muerte Madrid: Instituto de Salud Carlos III; 2002.

4. Ferlay J, Bray F, Pisani P, Parkin D: GLOBOCAN 2002: Cancer incidence, mortality and prevalence worldwide. In IARC CancerBase No.5. version 2.0 IARC Press, Lyon; 2004.

5. Chow WH, Devesa SS, Warren JL, Fraumeni JF Jr: Rising incidence of renal cell cancer in the United States. JAMA 1999, 28 | :|628-|63|.

6. Mathew A, Devesa SS, Fraumeni JF Jr, Chow WH: Global increases in kidney cancer incidence, 1973-1992. Eur J Cancer Prev 2002, I I: I7I-I 78 .

7. McLaughlin JK, Lipworth L, Tarone RE, Blot WJ: Renal Cancer. In Cancer epidemiology and prevention Edited by: Schottenfeld D, Fraumeni JF, Jr. New York: Oxford University Press; 2006.

8. Moore LE, Wilson RT, Campleman SL: Lifestyle factors, exposures, genetic susceptibility, and renal cell cancer risk: a review. Cancer Invest 2005, 23:240-255.

9. Kreiger N, Marrett LD, Dodds L, Hilditch S, Darlington GA: Risk factors for renal cell carcinoma: results of a population-based case-control study. Cancer Causes Control 1993, 4: I01-II0.

10. Wolk A, Gridley G, Niwa S, Lindblad P, McCredie M, Mellemgaard A, Mandel JS, Wahrendorf J, McLaughlin JK, Adami HO: International renal cell cancer study. VII. Role of diet. Int J Cancer 1996, 65:67-73.

II. Parker AS, Cerhan JR, Lynch CF, Ershow AG, Cantor KP: Gender, alcohol consumption, and renal cell carcinoma. Am J Epidemiol 2002, I 55:455-462

12. Setiawan WW, Stram DO, Nomura AM, Kolonel LN, Henderson BE: Risk factors for renal cell cancer: the multiethnic cohort. Am J Epidemiol 2007, 166:932-940. 
13. Greving JP, Lee JE, Wolk A, Lukkien C, Lindblad P, Bergstrom A: Alcoholic beverages and risk of renal cell cancer. $\mathrm{Br} J$ Cancer 2007, 97:429-433.

14. Cantor KP, Hoover R, Mason TJ, McCabe LJ: Associations of cancer mortality with halomethanes in drinking water. J Natl Cancer Inst 1978, 6I:979-985.

15. Villanueva CM, Cantor KP, Grimalt JO, Castano-Vinyals G, Malats N Silverman D, Tardon A, Garcia-Closas R, Serra C, Carrato A, Rothman N, Real FX, Dosemeci M, Kogevinas M: Assessment of lifetime exposure to trihalomethanes through different routes. Occup Environ Med 2006, 63:273-277.

16. Ward MH, Rusiecki JA, Lynch CF, Cantor KP: Nitrate in public water supplies and the risk of renal cell carcinoma. Cancer Causes Control 2007, I 8: I|4|-I I5I.

17. Ward MH, deKok TM, Levallois P, Brender J, Gulis G, Nolan BT, VanDerslice J: Workgroup report: Drinking-water nitrate and health - recent findings and research needs. Environ Health Perspect 2005, I | 3: |607-16|4.

18. Kurttio P, Auvinen A, Salonen L, Saha H, Pekkanen J, Makelainen I, Vaisanen SB, Penttila IM, Komulainen H: Renal effects of uranium in drinking water. Environ Health Perspect 2002, I I 0:337-342.

19. Garcia-Talavera M, Matarranz JL, Martinez M, Salas R, Ramos L: Natural ionizing radiation exposure of the Spanish population. Radiat Prot Dosimetry 2007, I 24:353-359.

20. Sainz C, Quindos LS, Fernandez PL, Gomez J, Fuente I, Quindos L, Matarranz JL: High background radiation areas: the case of Villar de la Yegua village (Spain). Radiat Prot Dosimetry 2007, I 25:565-567.

21. Isam Salih MM, Pettersson HB, Lund E: Uranium and thorium series radionuclides in drinking water from drilled bedrock wells: correlation to geology and bedrock radioactivity and dose estimation. Radiat Prot Dosimetry 2002, 1 02:249-258.

22. Lawson A, Biggeri A, Bohning D, Lesaffre E, Biggeri A, Viel J, et al.: Disease mapping and risk assessment for public health Chichester: Wiley; 1999.

23. Elliott $\mathrm{P}$, Wartenberg $\mathrm{D}$ : Spatial epidemiology: current approaches and future challenges. Environ Health Perspect 2004, I | 2:998-1006.

24. Elliott P, Wakefield JC, Best N, Briggs S: Spatial epidemiology New York: Oxford; 2000

25. Lopez-Abente G, Ramis R, Pollan M, Aragones N, Perez-Gomez B, Gomez-Barroso D, et al:: Atlas municipal de mortalidad por cáncer en España, 1989-19982006 [http://www.isciii.es/htdocs/centros/epide miologia/libros/Atlas municipal.pdf]. Madrid: Instituto de Salud Carlos III

26. Clayton D, Kaldor J: Empirical Bayes estimates of age-standardized relative risks for use in disease mapping. Biometrics 1987, 43:67|-68|

27. Besag J, York J, Molliè A: Bayesian image restoration, with two applications in spatial statistics (with discussion). Annals of the Institute of Statistical Mathematics 1991, 43:1-59.

28. Clayton DG, Bernardinelli L, Montomoli C: Spatial correlation in ecological analysis. Int J Epidemiol 1993, 22: I I93-I202.

29. Gilks W, Richardson S, Spiegelhalter D: Markov Chain Monte Carlo in Practice. Interdisciplinary Statistics Boca Raton, Florida: Chapman \& Hall/ CRC; 1995.

30. Spiegelhalter D, Thomas A, Best N, Lunn D: WinBUGS user manual. Version 1.4.I Cambridge: MRC; 2003.

31. Smith B: Bayesian Output Analysis Program (BOA). Version 0.99.I for S-PLUS and R 200I [http://www.public-health.uiowa.edu/ BOA].

32. Richardson $\mathrm{S}$, Thomson $\mathrm{A}$, Best $\mathrm{N}$, Elliott $\mathrm{P}$ : Interpreting posterior relative risk estimates in disease-mapping studies. Environ Health Perspect 2004, I I 2:1016-1025.

33. Perez-Gomez B, Aragones N, Pollan M, Suarez B, Lope V, Llacer A Lopez-Abente G: Accuracy of cancer death certificates in Spain: a summary of available information. Gac Sanit 2006 20(Suppl 3):42-5I.

34. McLaughlin JK, Lipworth L, Tarone RE: Epidemiologic aspects of renal cell carcinoma. Semin Oncol 2006, 33:527-533.

35. Lopez-Abente G, Aragones N, Ramis R, Hernandez-Barrera V, PerezGomez B, Escolar A, Pollan M: Municipal distribution of bladder cancer mortality in Spain: Possible role of mining and industry. BMC Public Health 2006, 6:17.

36. INE, MSyC: Encuesta Nacional de Salud (ENS). Ministerio de Sanidad y Consumo; 2003.
37. Garcia-Perez J, Boldo E, Ramis R, Pollan M, Perez-Gomez B, Aragones $N$, Lopez-Abente $G$ : Description of industrial pollution in Spain. BMC Public Health 2007, 7:40.

38. IARC: Overall Evaluations of Carcinogenicity to Humans. In Group I: Carcinogenic to humans Volume I-98. IARC Monographs; 2008.

39. Kolonel LN: Association of cadmium with renal cancer. Cancer 1976, 37:1782-1787.

40. II'yasova D, Schwartz GG: Cadmium and renal cancer. Toxicol Appl Pharmacol 2005, 207: I79-I86.

4I. Hu J, Mao Y, White K: Renal cell carcinoma and occupational exposure to chemicals in Canada. Occup Med (Lond) 2002, 52:157-164

42. Yang CY, Chiu HF, Wu TN, Chuang HY, Ho SC: Reduction in kidney cancer mortality following installation of a tap water supply system in an arsenic-endemic area of Taiwan. Arch Environ Health 2004, 59:484-488.

43. Sunderman FW Jr, Maenza RM, Hopfer SM, Mitchell JM, Allpass PR, Damjanov I: Induction of renal cancers in rats by intrarenal injection of nickel subsulfide. J Environ Pathol Toxicol 1979 , 2:|5||-|527.

44. Quindos Poncela LS, Fernandez PL, Gomez AJ, Sainz C, Fernandez JA, Suarez ME, Martin Matarranz JL, Cascon MC: Natural gamma radiation map (MARNA) and indoor radon levels in Spain. Environ Int 2004, 29:1091-1096

45. Fernandez CS, Lozano IC, Gomez JMG: Natural Radionuclides in Ground Water in Western Spain. Radiation Protection Dosimetry 1992, 45:227-229.

46. Zamora ML, Tracy BL, Zielinski JM, Meyerhof DP, Moss MA: Chronic ingestion of uranium in drinking water: a study of kidney bioeffects in humans. Toxicol Sci 1998, 43:68-77.

47. Ministerio de Industria y Energía: Libro blanco de las aguas subterráneas 1995 [http://hispagua.cedex.es/documentacion/documentos/libroa zul/libroblanco/libroblanco.htm]. Madrid: Ministerio de Industria y Energía

48. LAR-USC: Determinación de la concentración de 226Ra 222Rn, coeficientes alfa/beta total y contenido en $3 \mathrm{H}$ de las aguas minerales, minero-medicinales, de manantial y de consumo humano de Galicia. Laboratorio de análisis de radiaciones 2008 [http://www.usc.es/genp/lar/esp/proyectos/investig/aguas/inicio aguas.htm]. Universidad de Santiago de Compostela

49. Varela G, Moreiras O, Carbajal A, Campo M: Encuesta de presupuestos familiares. Estudio nacional de nutrición y alimentación Madrid: Instituto Nacional de Estadística; 1995.

50. Mahabir S, Leitzmann MF, Virtanen MJ, Virtamo J, Pietinen P, Albanes $D$, Taylor PR: Prospective study of alcohol drinking and renal cell cancer risk in a cohort of finnish male smokers. Cancer Epidemiol Biomarkers Prev 2005, I4: I70-175.

51. Nicodemus KK, Sweeney C, Folsom AR: Evaluation of dietary, medical and lifestyle risk factors for incident kidney cancer in postmenopausal women. Int J Cancer 2004, I 08: I I5-I2I.

52. Lee JE, Giovannucci E, Smith-Warner SA, Spiegelman D, Willett WC, Curhan GC: Total fluid intake and use of individual beverages and risk of renal cell cancer in two large cohorts. Cancer Epidemiol Biomarkers Prev 2006, I 5: I 204-I2 I I.

53. Requejo A, Ortega $R$, Robles B, Suárez A: Estudio sobre dietas $y$ hábitos alimentarios en la población española. Final report CSNCIEMAT. CSN. [1 0.2002]. Colección Documentos 2002.

54. Lee JE, Hunter DJ, Spiegelman D, Adami HO, Albanes D, Bernstein L, Brandt PA van den, Buring JE, Cho E, Folsom AR, Freudenheim JL, Giovannucci E, Graham S, Horn-Ross PL, Leitzmann MF, McCullough ML, Miller AB, Parker AS, Rodriguez C, Rohan TE, Schatzkin A Schouten LJ, Virtanen M, Willett WC, Wolk A, Zhang SM, SmithWarner SA: Alcohol intake and renal cell cancer in a pooled analysis of 12 prospective studies. J Natl Cancer Inst 2007, 99:801-810

55. Villanueva $C M$, Cantor KP, Grimalt JO, Malats $N$, Silverman D, Tardon A, Garcia-Closas R, Serra C, Carrato A, Castano-Vinyals G, Mar$\cos$ R, Rothman N, Real FX, Dosemeci M, Kogevinas M: Bladder cancer and exposure to water disinfection by-products through ingestion, bathing, showering, and swimming in pools. Am J Epidemiol 2007, I 65: | 48-I56.

56. Villanueva CM, Cantor KP, Cordier S, Jaakkola J], King WD, Lynch CF, Porru S, Kogevinas M: Disinfection byproducts and bladder cancer: a pooled analysis. Epidemiology 2004, 1 5:357-367. 
57. Dunnick JK, Melnick RL: Assessment of the carcinogenic potential of chlorinated water: experimental studies of chlorine, chloramine, and trihalomethanes. J Natl Cancer Inst 1993, 85:817-822.

58. Dunnick JK, Eustis SL, Lilja HS: Bromodichloromethane, a trihalomethane that produces neoplasms in rodents. Cancer Res 1987, 47:5189-5193.

59. Fields S: Global nitrogen: cycling out of control. Environ Health Perspect 2004, I I 2:A556-A563.

60. Bogovski P, Bogovski S: Animal Species in which $\mathbf{N}$-nitroso compounds induce cancer. Int J Cancer 198I, 27:47I-474.

6I. Hard GC: Mechanisms of chemically induced renal carcinogenesis in the laboratory rodent. Toxicol Pathol 1998, 26:104-II2.

62. Tricker AR: $\mathbf{N}$-nitroso compounds and man: sources of exposure, endogenous formation and occurrence in body fluids. Eur J Cancer Prev 1997, 6:226-268.

63. Ministerio de Medio Ambiente: Libro blanco del agua en España Madrid: Ministerio de Medio Ambiente; 2000.

\section{Pre-publication history}

The pre-publication history for this paper can be accessed here:

http://www.biomedcentral.com/1471-2407/8/293/pre pub

Publish with Bio Med Central and every scientist can read your work free of charge

"BioMed Central will be the most significant development for disseminating the results of biomedical research in our lifetime. "

Sir Paul Nurse, Cancer Research UK

Your research papers will be:

- available free of charge to the entire biomedical community

- peer reviewed and published immediately upon acceptance

- cited in PubMed and archived on PubMed Central

- yours - you keep the copyright

Submit your manuscript here:

http://www.biomedcentral.com/info/publishing_adv.asp 